\title{
Implementasi Akuntansi Sistem Pembelian dan Penjualan Obat Dengan Menggunakan Aplikasi MYOB Accounting Pada Praktek Kedokteran
}

\author{
Anik Wahyuningsih \\ Program Studi Komputerisasi Akuntansi \\ STMIK Cikarang, Bekasi, Jawa Barat \\ anik_naufal@yahoo.com
}

\begin{abstract}
Praktek Dokter Roy Jhanna Ginting merupakan badan usaha yang bergerak dalam bidang kesehatan termasuk juga dalam bidang penjualan dan pembelian obat. Praktek Dokter Roy Jhanna Ginting ini didirikan oleh dr. Roy Jhanna Ginting bersama dengan istrinya dr. Grace Ulina Hutabarat dan berdiri sejak tahun 2010. Penjualan dan pembelian tunai merupakan salah satu kegiatan penting dalam setiap perusahan, terutama yang bergerak dibidang perdagangan. Transaksi penjualan dan pembelian yang ada pada Praktek Dokter Roy Jhanna Ginting dimulai dari proses pesanan barang oleh pelanggan, proses pembuatan nota sebagai barang bukti pembayaran, sampai pembuatan laporan yang ditunjukkan kepada pimpinan. Sistem pengolahan data penjualan dan pembelian tunai pada Praktek Dokter Roy Jhanna Ginting sampai saat ini masih dilakukan secara manual, mulai dari proses pemesanan barang, pembuatan nota, pembayaran, hingga pembuatan laporan. Sehingga sering terjadi keterlambatan dan kesalahan informasi yang dihasilkan seperti pembuatan laporan data barang yang dipesan dan yang terjual, seringnya terjadi kesalahan dalam perhitungan dalam sistem penjualan dan pembelian tunai tersebut. Untuk mengatasi masalah tersebut, maka diperlukan suatu sistem komputerisasi penjualan dan pembelian tunai yang sangat sesuai untuk medukung kemajuan dan perkembangan perusahaan dagang tersebut. Sehingga dapat mengatasi permasalahan atau kendala pada sistem yang sedang berjalan saat ini. Dengan memanfaatkan sistem komputerisasi yang diusulkan ini, kemungkinan proses penjualan dan pembelian tunai yang dilakukan menjadi lebih mudah dan cepat.
\end{abstract}

Kata Kunci-MyOB, Accounting, Sistem Informasi

\section{Pendahuluan}

Didalam dunia bisnis sekarang ini perkembangan teknologi informasi dan persaingan usaha dalam berbagai bidang mengakibatkan pelaku-pelaku ekonomi harus dapat mengakses secara cepat dan tepat informasi baik dari dalam maupun dari luar perusahaan. Informasi-informasi tersebut merupakan kebutuhan dalam mencapai tujuan yang telah disepakati secara bersama sehingga tercapai secara maksimal.
Keberhasilan suatu perusahaan dalam mencapai suatu tujuan yang telah disepakati bersama tidak terlepas dari sistem-sistem yang menyediakan informasi-informasi yang akurat dan terpercaya. Kita juga harus menyadari bahwasanya inovasi dalam perkembangan teknologi informasi berkembang pesat dan selaras dengan karakteristik masyarakat modern yang memiliki mobilitas tinggi, sehingga membuat mereka untuk mencari layanan yang cepat dan mudah. Hal itulah yang menjadi motivasi bagi kita agar dapat meningkatkan kemampuan untuk memuaskan pelanggan kita. Perbedaan kualitas pelayanan dalam persaingan dibidang usaha perdagangan dan sebagainya datang dari perbedaan kualitas pelayanan yang kita berikan. Untuk itu pemanfaatan teknologi informasi sangat diperlukan khususnya untuk sistem pembelian dan penjualan obat yang ada pada Praktek

Dokter Roy Jhanna Ginting untuk menangani transaksi keuangan yang masih manual yang kemudian akan dibuat menjadi sebuah sistem informasi yang terkomputerisasi dan akurat dengan menggunakan aplikasi akuntansi yaitu MYOB Accounting dan diharapkan lebih baik dari sistem manual, sehingga pada proses transaksi tersebut dapat mengolah data dengan cepat, tepat dan akurat.

\section{LANDASAN TEORI}

\section{A. Teori Akuntansi}

\section{1) Pengertian Akuntansi}

Pengertian akuntansi dari sudut pandang pengguna akuntansi, yaitu suatu disiplin ilmu dan atau aktivitas jasa yang menyediakan informasi yang diperlukan untuk melaksanakan kegiatan secara efisien dan mengevaluasi kegiatan suatu entitas atau transaksi yang bersifat keuangan (finansial). Adapun dari sudut pandang proses kegiatannya, akuntansi adalah proses pencatatan, penggolongan, peringkasan. Pelaporan dan penganalisaan data keuangan suatu entitas.

Dari pengertian diatas dapat diambil kesimpulan bahwa sistem akuntansi dibuat untuk memberikan informasi 
keuangan yang dibutuhkan oleh manajemen sebuah perusahaan guna memudahkan pengelolaan perusahaan.

\section{2) Pengertian Sistem Informasi Akuntansi}

Merupakan sistem informasi fungsional yang mendasari sistem informasi fungsional yang lainnya seperti sistem informasi keuangan, sistem informasi pemasaran, sistem informasi produksi dan sistem informasi sumber daya manusia. Sistem-sistem informasi lain membutuhkan data keuangan dari system informasi akuntansi.

Suatu sistem dapat didefenisikan sesuatu yang memiliki bagian-bagian yang saling berinteraksi untuk mencapai tujuan tertentu melalui tiga tahapan yaitu :

- Input

- Proses

- Output

Sistem informasi adalah sebuah rangkaian prosedur formal dimana data dikumpulkan, diproses menjadi informasi dan didistribusikan kepada para pemakai atau pengguna.

Adapun tujuan sistem informasi akuntansi adalah :

- Untuk menyediakan informasi bagi pengelolaan kegiatan usaha baru.

- Untuk memperbaiki informasi yang dihasilkan oleh sistem yang sudah ada baik mengenai mutu, ketepatan penyajian maupun struktur informasinya.

- Untuk memperbaiki pengendalian akuntansi dan pengecekan intern yaitu : untuk memperbaiki tingkat keandalan informasi akuntansi dan untuk menyediakan catatan lengkap mengenai pertanggungjawaban dan perlindungan kekayaan perusahaan.

- Untuk mengurangi biaya dalam penyelenggaraan catatan akuntansi.

\section{3) Laporan Keuangan}

Laporan Keuangan yang utama terdiri dari :

- Laporan Laba / Rugi

Adalah laporan yang memuat pendapatan dan beban/biayausaha dalam suatu periode tertentu. Selisih antara pendapatan dan beban/biaya disebut laba bersih (net income) atau rugi bersih (lost income).

- Laporan Perubahan Modal

Adalah laporan mengenai perubahan modal pemilik suatu badan usaha selama satu periode. Laporan ini menggambarkan bertambah atau berkurangnya modal dibandingkan pada periode sebelumnya.

- Laporan Neraca

Adalah laporan keuangan yang menggambarkan posisi keuangan suatu entitas pelaporan pada tanggal tertentu. Yang dimaksud dengan posisi keuangan adalah posisi aset, kewajiban dan ekuitas dana.

\section{B. Teori Aplikasi $M y O B$}

MYOB (Mind Your Own Bussiness) dimulai di Australia pada tahun 1991 dan merupakan salah satu perusahaan yang sukses mengenali kebutuhan yang unik dari perusahaan kecilmenengah sampai perusahaan menengah-besar akan sistem manajemen bisnis (Bussiness Management Systems) yang powerful, mudah dan terjangkau. Banyak penghargaan yang diterima oleh jajaran produk MYOB sejak 1991 sampai sekarang. Sukses ini kemudian berkembang ke seluruh dunia.

MYOB merupakan paket program komputer untuk olah data akuntansi yang dibuat secara terpadu (integrated software). MYOB sudah menyediakan chart of account (daftar rekening) siap pakai menggunakan bahasa Inggris untuk 105 jenis perusahaan.

Adapun keunggulan yang didapat dari MYOB yaitu :

- Sistem Pembukuan Terintegrasi

MYOB memberikan kemudahan dalam proses administrasi usaha dengan mengintegrasikan fugsi-fungsi buku besar, pembelian, penjualan, keuangan dan persediaan memberikan efisiensi kerja dengan pencatatan melalui fungsi-fungsi yang berbeda dan memungkinkan eksplorasi data yang maksimal.

- Otomatisasi Pembukuan

Dalam program MYOB banyak sekali fungsi yang dapat diatur untuk mempermudah penggunaan, salah satunya adalah otomatisasi proses pembukuan dengan menggunakan link account (link perkiraan transaksi) yang akan mengambil alih proses pembukuan mulai dari proses penjurnalan, posting sampai penyusunan laporan dan proses analisa bahkan fungsi pengendalian operasional. Dengan demikian, pengguna tidak perlu melakukan proses posting ke buku besar, melakukan proses summary dan filtering buku besar untuk menghasilkan laporan yang diinginkan.

- Integarsi Dengan Microsoft Office

MYOB juga berintegrasi dengan Microsoft Office, sehingga data/laporan akan dengan mudah dikonversi ke Microsoft Excel untuk diolah lebih lanjut ke HTML untuk pengiriman yang lebih mudah melalui internet.

- Mendukung Penggunaan Secara Multi User

Untuk mendukung integrated systems ini, selain digunakan secara singleuser, MYOB juga digunakan secara multiuser, sehingga data dapat diinput oleh pengguna lainnya. MYOB dapat berjalan pada semua jenis jaringan populer, secara peer-to-peer atau server-client network.

- Eksplorasi Database Yang Maksimal

Dengan modul-modul analisa, pencarian transaksi tugas (to do list) dan fungsi laporan dengan fungsi filtering dan designing, MYOB memberikan keleluasaan bagi penggunanya untuk mengeksplorasi database yang ada dan menampilkannya dalam beragam format seperti : laporan form faktur, analisa grafis dan lain-lain. Dengan adanya 
modul-modul tersebut diatas, MYOB selain membantu penggunanya dalam meningkatkan efisiensi dan simplifikasi kerja, juga dalam fungsi pengendalian operasional perusahaan.

\section{Teori Pendukung}

Teori pendukung yang berbubungan dengan sistem terkait adalah sebagai berikut :

\section{1) Penjualan}

Penjualan adalah pendapatan lazim dalam perusahaan dan merupakan jumlah kotor yang dibebankan kepada pelanggan atas barang dan jasa. Penjualan artinya penjualan barang dagangan sebagai usaha pokok perusahaan yang biasanya dilakukan secara teratur.

Secara umum defenisi penjualan adalah sebagai sebuah usaha atau langkah konkrit yang dilakukan untuk memindahkan suatu produk, baik itu berupa barang atau jasa, dari produsen kepada konsumen sebagai sasarannya. Tujuan utama penjualan yaitu mendatangkan keuntungan atau laba dari produk ataupun barang yang dihasilkan produsennya dengan pengelolaan yang baik.

\section{2) Jenis-jenis Penjualan}

Penjualan dapat dibedakan menjadi :

- Penjualan Langsung, yaitu suatu proses membantu dan membujuk satu atau lebih calon konsumen untuk membeli barang atau jasa atau bertindak sesuai ide tertentu dengan menggunakan komunikasi tatap muka.

- Penjualan Tidak Langsung, yaitu bentuk presentase dan promosi gagasan barang dan jasa dengan menggunakan media tertentu seperti surat kabar, majalah, radio, televisi, papan iklan, brosur dan lainlain

\section{3) Pembelian}

Pembelian adalah suatu usaha yang dilakukan untuk pengadaan barang yang diperlukan oleh perusahaan [1].

Jenis pembelian berdasarkan pemasok:

- $\quad$ Pembelian lokal adalah pembelian dari pemasok yang berasal dari dalam negeri.

- Pembelian impor adalah pembelian dari pemasok yang berasal dari luar negeri.

Jenis pembelian berdasarkan transaksi :

- Transaksi pembelian tunai adalah jenis transaksi dimana pembayarannya dilakukan secara langsung pada saat barang diterima.

- Transaksi pembelian kredit adalah jenis transaksi dimana pembayarannya tidak dilakukan secara langsung pada saat barang diterima tetapi dilakukan selang beberapa waktu setelah barang diterima, sesuai perjanjian kedua belah pihak.

\section{ANALISA Sistem}

\section{A. Proses Bisnis}

Mengumpulkan, mengkaji dan memproses data mengenai kegiatan bisnis organisasi secara efektif, efisien dan menyediakan informasi yang berguna untuk pengambilan keputusan serta membentuk pengendalian yang memadai untuk memastikan bahwa bisnis dicatat dan diproses secara akurat serta untuk melindungi data dan aset organisasi lainnya yang merupakan tiga dasar fungsi yang harus dilaksanakan dalam sistem informasi. Oleh karena itu dalam membahas sistem berjalan yang terdiri dari proses-proses dalam melakukan berbagai kegiatan dan dalam penyusunan laporan pada sistem pemjualan dan pembelian obat, maka penyusun mengelompokkan prosedur tersebut kedalam proses kegiatan yang akan dijelaskan sebagai berikut :

1) Proses Pendataan Obat

Pimpinan menyerahkan daftar harga obat ke bagian administrasi atau penjualan, kemudian bagian penjualan mencatat data obat yang diterima dari pimpinan.

2) Proses Pencatatan Data Pelanggan

Pendataan pelanggan dimulai dengan pelanggan memberikan datadatanya kepada bagian administrasi atau penjualan, kemudian bagian penjualan mencatat data pelanggan tersebut dengan baik.

\section{3) Proses Penjualan Obat}

Pelanggan melakukan pemesanan obat dengan datang langsung ke Praktek Dokter Roy Jhanna, bagian penjualan terima pesanan. Kemudian bagian penjualan mengecek obat yang dipesan oleh pelanggan tersebut, apabila obat yang dipesan tidak ada maka bagian penjualan melakukan konfirmasi kepada pelanggan, dan apabila obat yang dipesan ada maka bagian penjualan mempersiapkan obat yang dipesan dan membuatkan nota, kemudian menyerahkan nota dan barang kepada pelanggan dan pelanggan akan menerima nota dan barang. Setelah pelanggan menerima nota, pelanggan melakukan pembayaran sesuai dengan nota dan bagian penjualan menerima pembayaran barang dari pelanggan.

\section{4) Proes Pembelian Obat}

Pembelian dimulai ketika bagian pembelian atau pimpinan melakukan pemesanan barang kepada supplier dan menyebutkan data obat yang akan dipesan. Berdasarkan data pesanan tersebut supplier mencatat dan mengecek daftar barang dan harga. Jika barang tidak tersedia, maka supplier mengkonfirmasikan kepada bagian pembelian, tetapi apabila barang tersedia, maka supplier akan menyiapkan barang dan mengkonfirmasikan jumlah pembelian kepada bagian pembelian. Pada proses ini, bagian pembelian melakukan pembayaran di Praktek Dokter Roy Jhanna Ginting, karena supplier akan mengantarkan obatnya langsung ke 
Praktek Dokter Roy dengan membawa nota atau faktur penjualan yang berisikan nominal yang harus dibayarkan oleh Dokter Roy kepada supplier. Kemudian bagian pembelian akan menyesuaikan barang yang diterima dengan nota atau faktur yang diberikan oleh supplier.

\section{5) Proses Pembuatan Laporan Penjualan}

Pada akhir bulan bagian penjualan membuat rincian laporan penjualan berdasarkan nota dari hasil penjualan obat yang akan diserahkan kepada pimpinan.

6) Proses Pembuatan Laporan Pembelian

Pada tahap ini, bagian pembelian membuat laporan pembelian dan laporan pengeluaran kas yang akan diberikan kepada pimpinan sebagai pertanggungjawaban dalam kurun waktu tetentu.

\section{B. Activity Diagram}

Activity diagram dibawah ini menggambarkan proses bisnis sistem berjalan yang ada pada Praktek Dokter Roy Jhanna . Berikut Activity Diagram dibawah ini :

1) Pendataan Obat

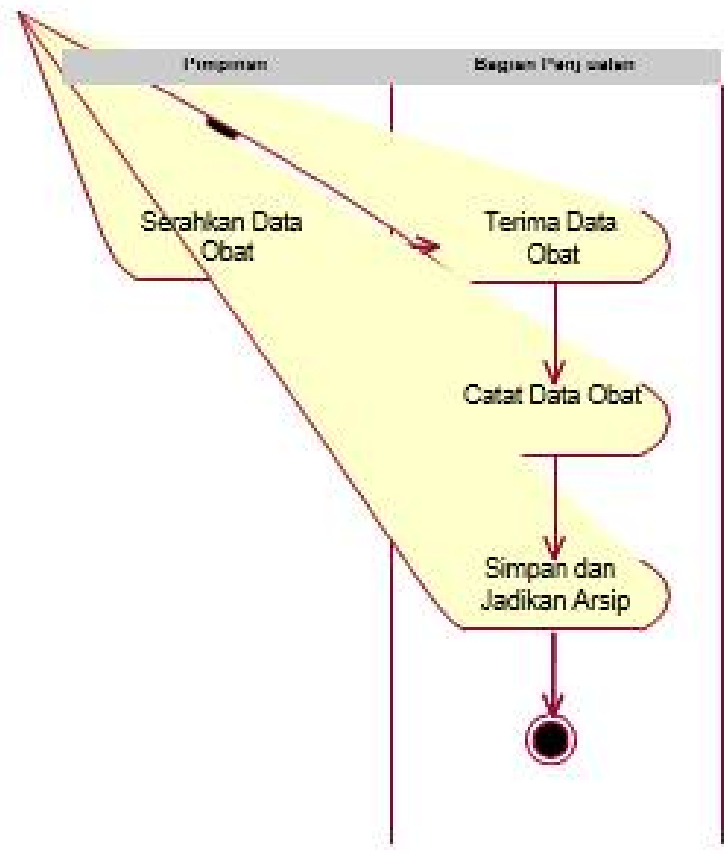

Gambar 1. Activity Diagram Pendataan Obat
2) Pencatatan Data Pelanggan

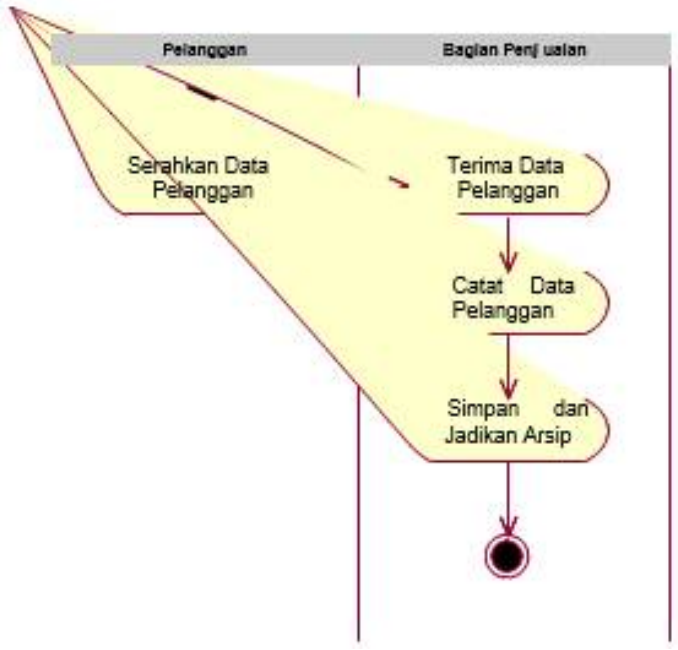

Gambar 2. Activity Diagram Pencatatan Data Pelanggan

\section{3) Penjualan Obat}

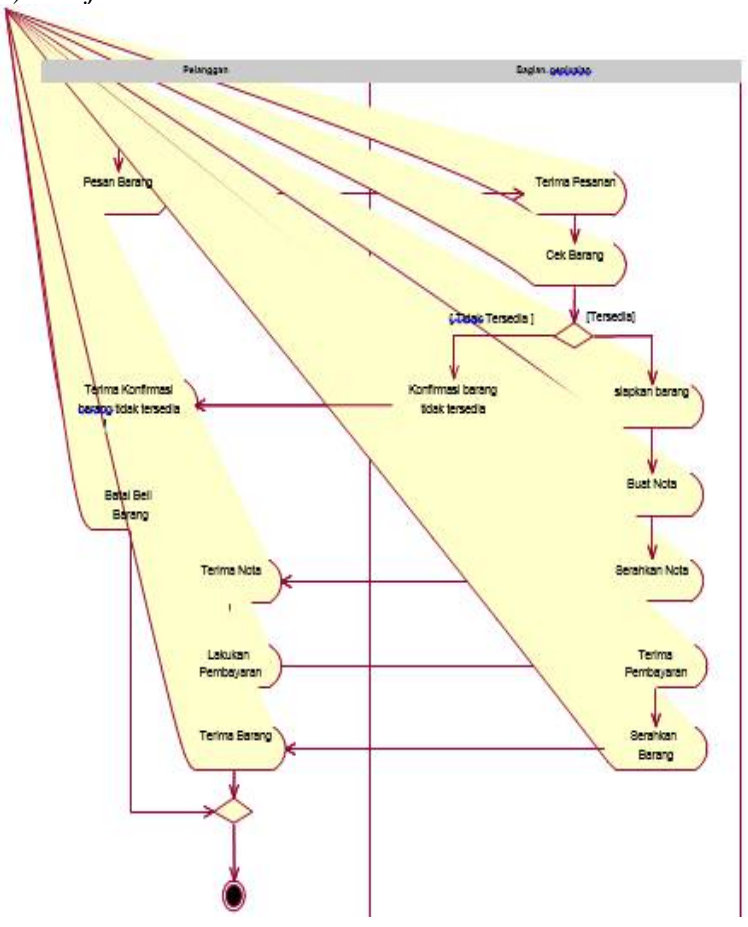

Gambar 3. Activity Diagram Penjualan Obat 


\section{4) Pembelian Obat}

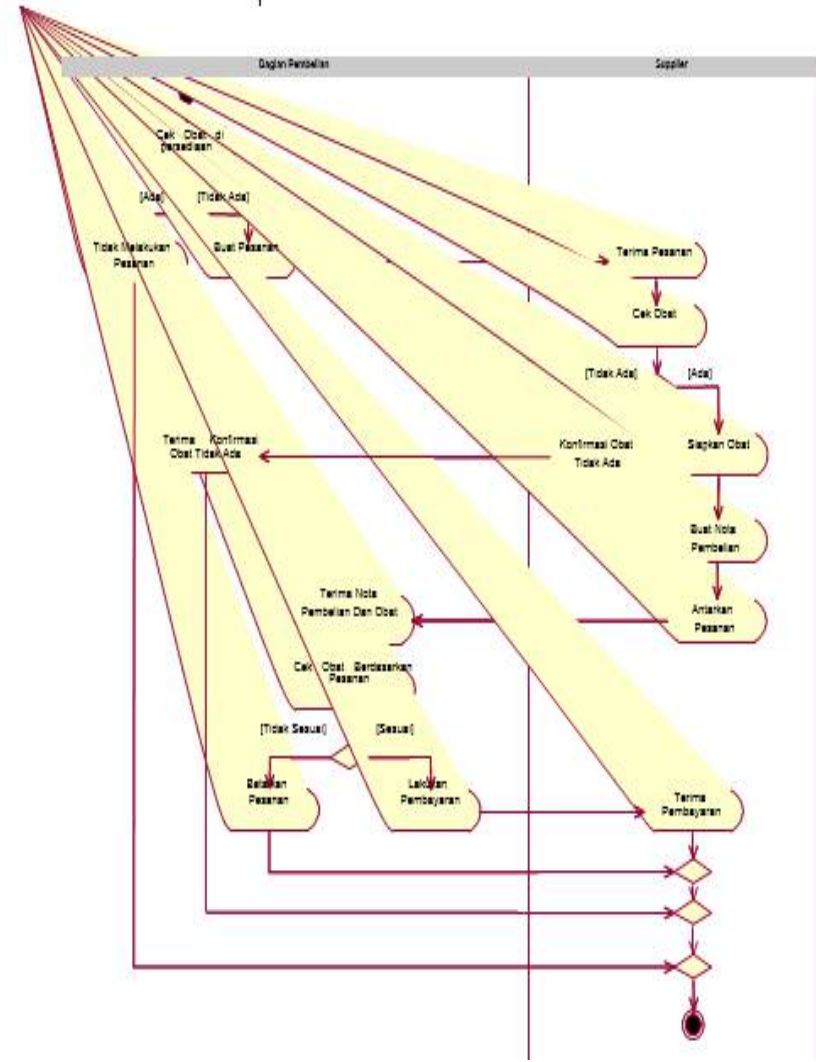

Gambar 4. Activity Diagram Pembelian Obat

\section{5) Laporan Penjualan}

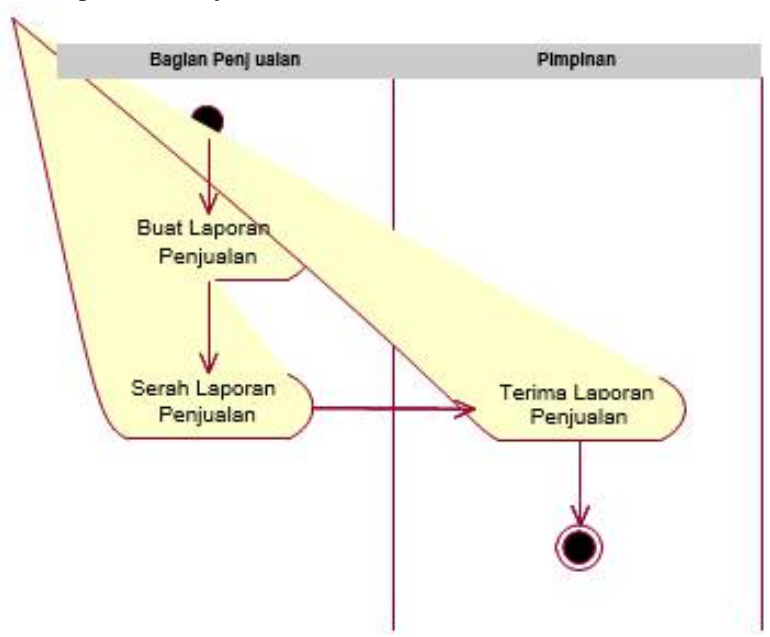

Gambar 5. Activity Diagram Laporan Penjualan

\section{6) Laporan Pembelian}

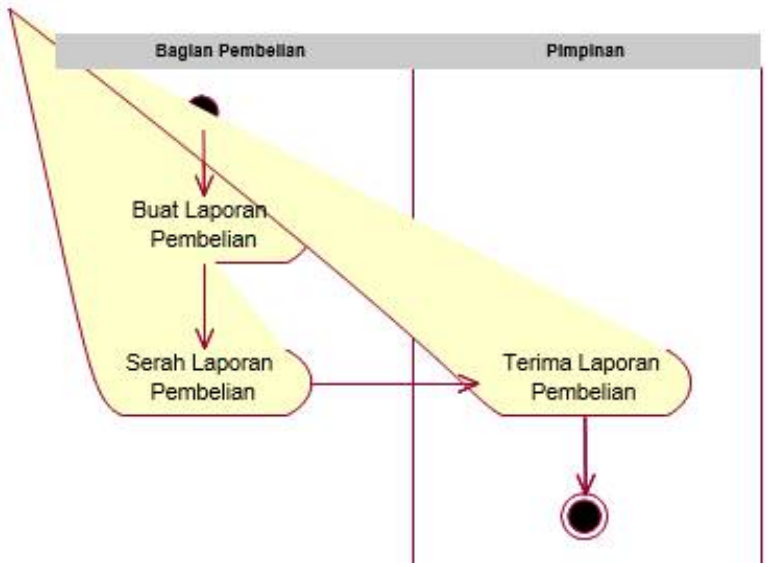

Gambar 6. Activity Diagram Pembuatan Laporan Pembelian

IV. IMPLEMENTASI AKUNTANSI

A. Tampilan Layar

1) Struktur Tampilan

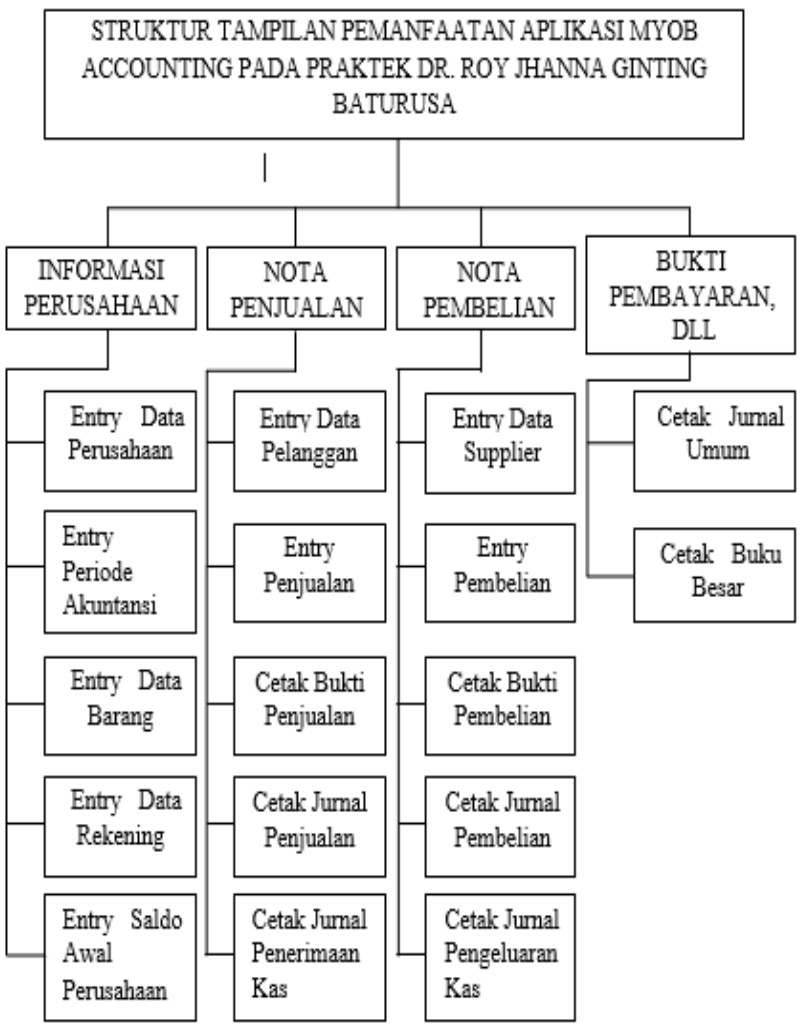

Gambar 7. Struktur Tampilan 


\section{B. Rancangan Layar}

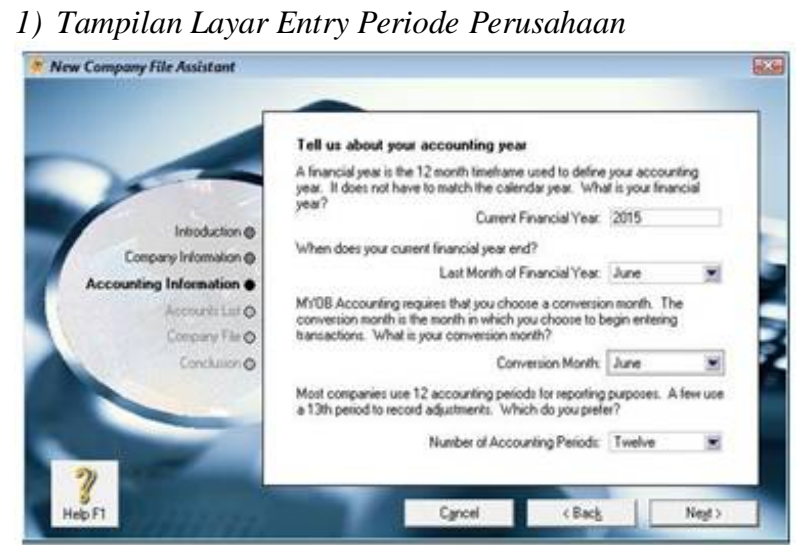

Gambar 8. Tampilan Layar Entry Periode Perusahaan

\section{2) Tampilan Layar Menu Awal}

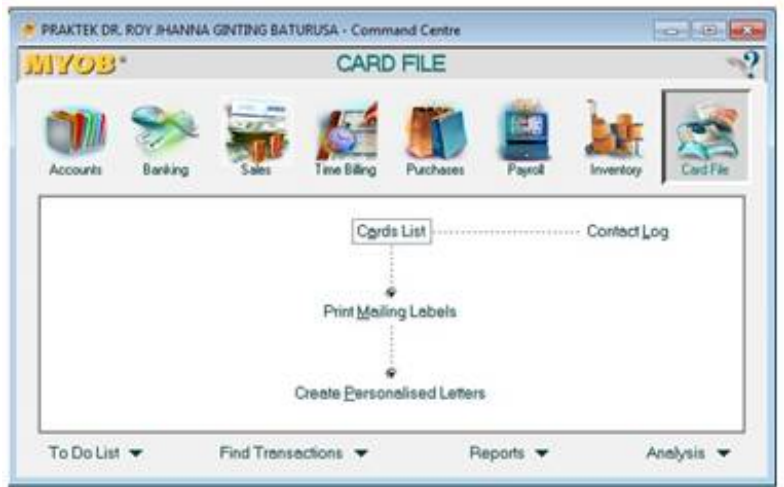

Gambar 9. Tampilan Layar Menu Awal

\section{3) Tampilan Layar Entry Data Pelanggan}

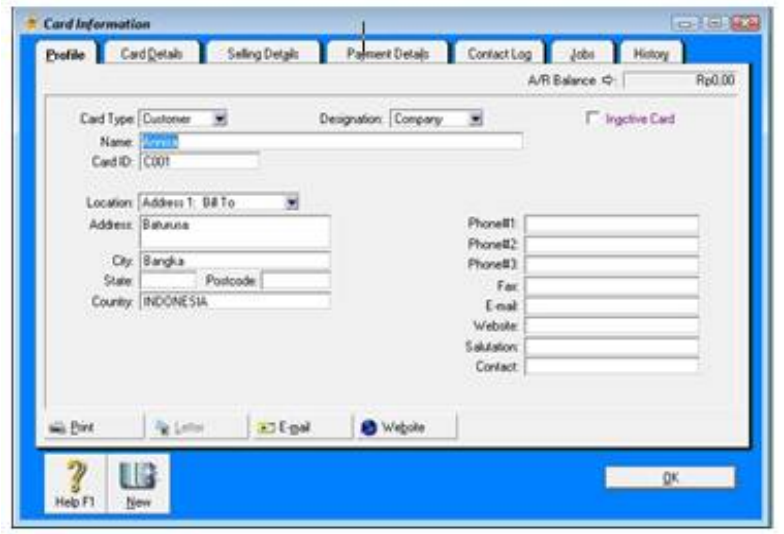

Gambar 10. Tampilan Layar Entry Data Pelanggan
4) Tampilan Layar Entry Data Barang

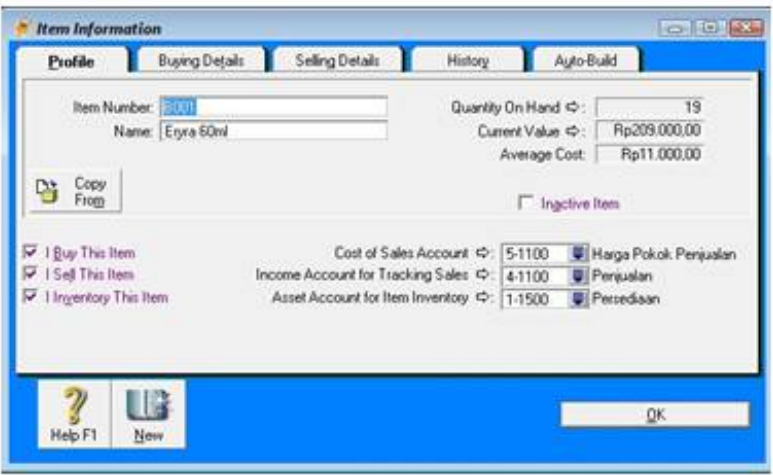

Gambar 11. Tampilan Layar Entry Data Barang

5) Tampilan Layar Entry Transaksi Penjualan

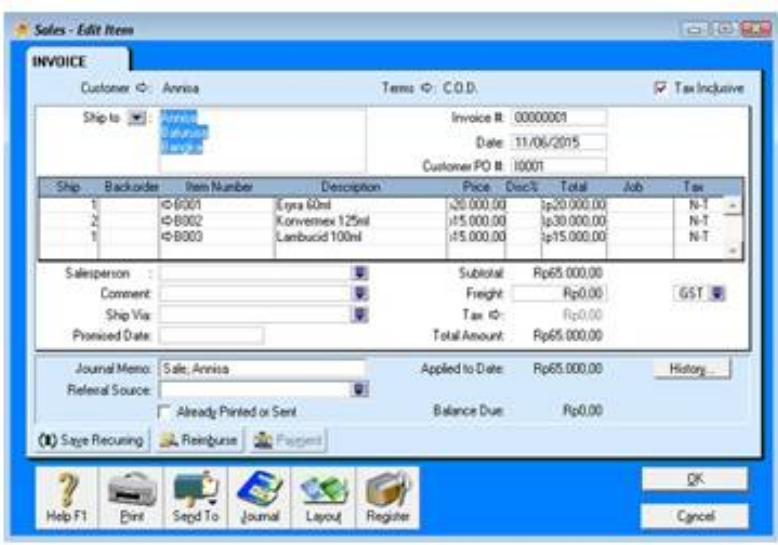

Gambar 12. Tampilan Layar Entry Transaksi Penjualan

6) Tampilan Layar Entry Transaksi Pembelian

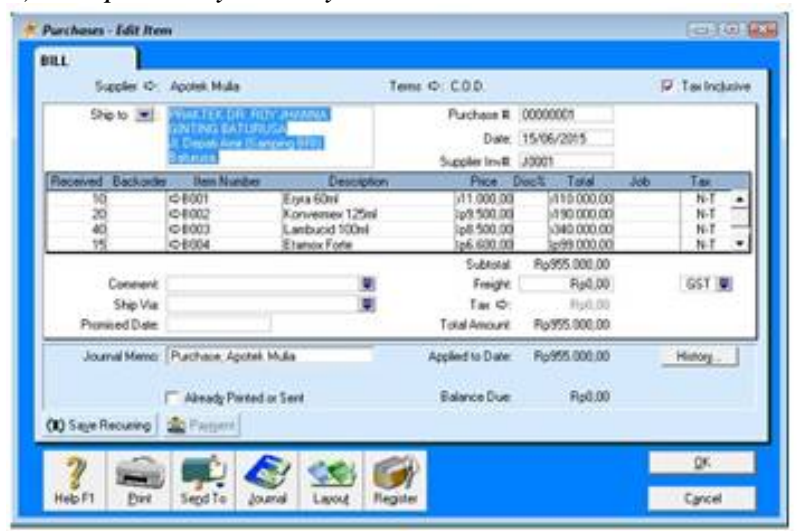

Gambar 13. Tampilan Layar Entry Transaksi Pembelian 


\section{7) Tampilan Layar Cetak Jurnal Penjualan}

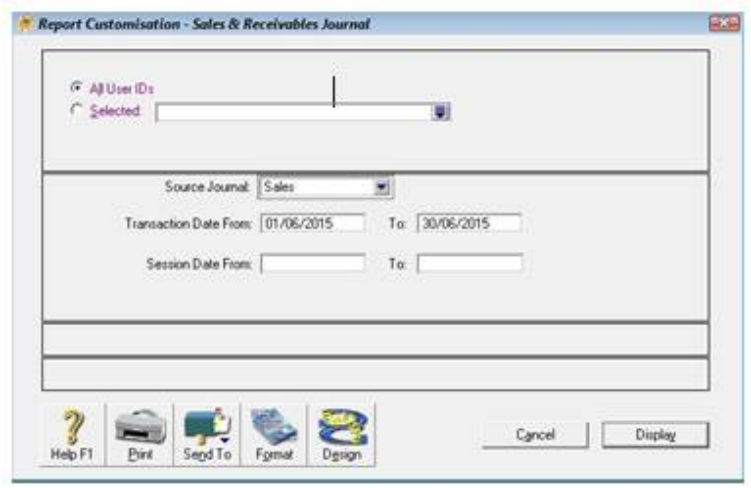

Gambar 14. Tampilan Layar Cetak Jurnal Penjualan

\section{8) Tampilan Layar Cetak Jurnal Pembelian}

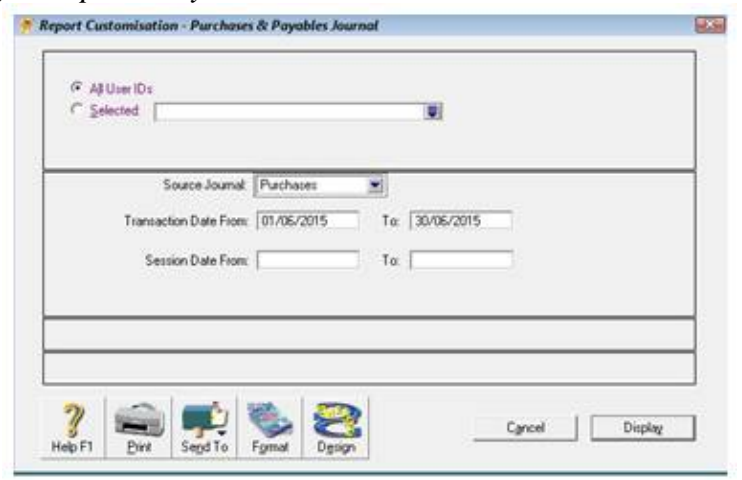

Gambar 15. Tampilan Layar Cetak Jurnal Pembelian

\section{Penutup}

\section{A. Kesimpulan}

Kesimpulan yang dapat ditarik dalam sistem penjualan dan pembelian ini antara lain :

- Penggunaan sistem penjualan dan pembelian secara manual memerlukan waktu yang lebih banyak serta keakuratan data atau informasi yang kurang terjamin. Padahal kegiatan penjualan dan pembelian merupakan kegiatan rutinitas setiap bulannya dan memerlukan ketelitian yang cukup.

- Tingkat kesalahan pada penggunaan sistem manual lebih besar dibandingkan dengan menggunakan sistem yang sudah terkomputerisasi seperti dalam proses perhitungan.

- Dengan adanya sistem penjualan dan pembelian secara komputerisasi pengolahan data, penyajian informasi pembelian akan lebih cepat, serta keakuratan data akan lebih terjamin karena tempat atau media penyimpanan lebih terjaga.
- Dengan menggunakan system penjualan dan pembelian yang sudah terkomputerisasi diharapkan masalah atau hambatan yang dihadapi dalam sistem manual dapat teratasi atau meminimalkan kesalahan yang terjadi dalam sistem manual yang kurang cepat dan keakuratan data yang kurang terjamin.

\section{B. Saran}

Maju atau tidaknya suatu instansi dalam usaha peningkatan kesejahteraan anggota sesuai dengan misi perusahaan itu sendiri, salah satu penyebabnya didukung oleh efisiensinya suatu pekerjaan yang dilakukan personil-personil yang terlibat dalam instansi tersebut. Untuk itu, dalam kesempatan ini penulis memberikan saran-saran untuk kelancaran sistem penjualan dan pembelian pada Praktek Dokter Roy Jhanna Ginting sebagai berikut :

- Untuk mengatasi masalah yang terjadi pada sistem penjualan dan pembelian, maka penulis menganjurkan agar sistem penjulan dan pembelian dilakukan secara komputerisasi, agar sistem tersebut menjadi lebih efektif dan efisien.

- Dengan sistem komputerisasi diharapkan pula dapat melakukan penyimpanan data secara tertib, aman dan terhindar dari hal-hal yang tidak diinginkan.

- Dengan sistem imformasi penjualan dan pembelian ini dapat diperoleh data yang yang akurat seandainya diperlukan dalam waktu singkat, dan dapat membantu kinerja dalam meningkatkan penjualan dan pembelian sehingga memudahkan dalam membuat informasi penjualan dan pembelian yang diinginkan.

- Selain itu sistem yang sudah terkomputerisasi juga perlu dilakukan pemeliharaan hardware dan software. Pemeliharaan hardware berupa kebersihan, pemeliharaan software seperti pemeriksaan dan pembersihan yang dilakukan oleh teknisi komputer.

\section{DAFTAR PUSTAKA}

[1] Mulyadi. Sistem Akuntasi. Yogyakarta : Sekolah Tinggi ilmu Ekonomi YKPN, 1997.

[2] Mulyadi, Sistem Akuntansi . Edisi 2. Yogyakarta : Sekolah Tinggi Ilmu Ekonomi YKPN, 2001.

[3] Jusuf, AL. Haryono. Dasar-Dasar Akuntansi.Edisi 6.Yogyakarta : SekolahTinggi Ilmu Ekonomi YKPN, 2002.

[4] Wahana Komputer. Tim Penelitian dan Pengembangan. 2005 Pengembangan Aplikasi Sistem Informasi Akademik Berbasis SMS dengan JAVA. Edisi Pertama. Salemba Infotek : Jakarta.

[5] Purnama Rangsang. 2003. Tuntunan Pemrograman Java Jilid 2. Tim Prestasi Pustaka: Surabaya. 